\title{
Reducing the length of hospital stay after total knee arthroplasty: influence of femoral and sciatic nerve block
}

\author{
Lúcio Honório de Carvalho Júnior ${ }^{1}$, Eduardo Frois Temponi ${ }^{1 *}$, Vinícius Oliveira Paganini ${ }^{1}$, Lincoln Paiva Costa ${ }^{1}$, \\ Luiz Fernando Machado Soares ${ }^{1}$, Matheus Braga Jacques Gonçalves ${ }^{1}$

Study conducted at the Hospital Madre Teresa - Belo Horizonte

Article received: $4 / 28 / 2014$ Accepted for publication: 6/3/2014

*Correspondence: Address: Avenida Raja Gabaglia, 1002 Postal Code: 30430-142 Bairro Gutierrez, Belo Horizonte - MG - Brazil dufrois@hotmail.com

http://dx.doi.org/10.1590/1806-9282.61.01.040 Conflict of interest: none

\section{SUMMARY}

Objective: the aim of this study is to evaluate the change in length of hospital stay postoperatively for Total Knee Arthroplasty after using femoral and sciatic nerve block.

Materials and methods: the medical records of 287 patients were evaluated, taking into account the number of hours of admission, the percentage and the reason for re-hospitalization within 30 days, as well as associated complications. All patients were divided into two groups according or not to whether they were admitted to ICU or not. During the years 2009 and 2010, isolated spinal anesthesia was the method used in the procedure. From 2011 on, femoral and sciatic nerve blocking was introduced.

Results: between the years 2009 and 2012, the average length of stay ranged from 74 hours in 2009 to 75.2 hours in 2010. The average length of stay in 2011 was 56.52 hours and 53.72 hours in 2012, all in the group of patients who did not remain in the ICU postoperatively. In the same period, among those in the group that needed ICU admission, the average length of stay was 138.7 hours in 2009, 90.25 hours in 2010, 79.8 hours in 2011, and 52.91 hours in 2012. During 2009 and 2010, the rate of re-hospitalization was 0\%, while in 2011 and 2012 , were $3.44 \%$ and $1 \%$, respectively.

Conclusion: according to this study, the use of femoral and sciatic nerve blocking after total knee arthroplasty allowed significant reduction in hospital stay.

Keywords: knee prosthesis, length of stay, anesthetic adjuvants.

\section{INTRODUCTION}

Osteoarthritis of the knee is a debilitating and increasingly common disease, and Total Knee Arthroplasty (TKA) is an effective procedure used as a definitive treatment. ${ }^{1,2}$ Recent estimates suggest that this demand is growing and could increase $673 \%$ by $2030 .{ }^{3}$ Although TKA can reduce pain and improve function in patients with osteoarthritis, it is a costly procedure. Dailey et al. ${ }^{4}$ and Losina et al. ${ }^{5}$ showed a readmission rate among beneficiaries of health plans at 19.6\% with an estimated cost of U\$17.4 billion. ${ }^{4,5}$ Equipment, professional, and facilities required for TKA account for part of the cost, but hospital length of stay (LS) after the procedure contributes greatly to price increase.

Several authors have shown that the average LS after TKA is between 5 and 9.4 days. ${ }^{6-8}$ Factors contributing to LS include preoperative, intraoperative and postoperative variables. Hospital factors and factors related to patients can also influence it. Risk factors associated with prolonged LS after TKA are: female gender, advanced age, obesity, American Society of Anesthesiologists physical status classification system (ASA) higher than score II, large surgical incisions, longer operative time, need for blood transfusion, difficulty in controlling pain and postoperative complications. ${ }^{8-13}$ Adequate control of these factors leads to reduced LS and costs.

Postoperative pain control is an important aspect to be considered. Severe pain occurs in $60 \%$ of patients undergoing TKA, and moderate pain in $30 \%$. Adequate pain control allows for early rehabilitation, greater short-term satisfaction and shorter LS. ${ }^{14-17}$ The goal in this study is to assess the change in LS after TKA surgery using femoral and sciatic nerve blocking. 


\section{Material AND MEthods}

In this retrospective, cross-sectional study, based on analysis of medical records, 287 patients undergoing TKA at Madre Teresa Hospital, Belo Horizonte, MG, Brazil, were assessed between 2009 and 2012 by one of the authors Lúcio Honório de Carvalho Júnior. The following information was obtained: number of hours of admission during those four years, demographics, ASA score, rate and reason for readmission within 30 days.

All patients undergoing TKA during the study period were eligible for the study, provided that they agreed to participate. Patients with incomplete data or who did not wish to participate in the study were excluded. 260 (90.5\%) patients were included in the study, 203 male and $57 \mathrm{fe}$ male, with a mean age of $71.9 \pm 7.8$ years ( $52-87$ years). The right knee was surgically treated in $70 \%$ of patients. The average height was $1.65 \pm 0.05$ meters ( 1.55 - 1.78 meters) and the average weight, $68 \pm 4 \mathrm{~kg}(54-97 \mathrm{~kg})$. For data analysis, patients were divided into two groups according to whether or not they were nursed postoperatively in the intensive care unit (ICU). 230 (88.5\%) patients did not require post-operative care in ICU, with a mean age of $71.9 \pm 7.2$ years ( $52-85$ years), while 30 (11.5\%) patients were admitted to ICU during the immediate postoperative period, with a mean age of $78.5 \pm 7$ years $(55$ 87 years).

In 2009 and 2010, the anesthetic technique used for the procedure was spinal anesthesia with 12 to $15 \mathrm{mg}$ of isobaric ropivacaine combined with $0.2 \mathrm{mg}$ of morphine. In January 2011, there was a change in protocol, and peripheral and neuraxial nerve block techniques were combined. The dose of ropivacaine was maintained without increase of morphine for spinal anesthesia and femoral and sciatic nerve blocking after surgery $(0.5 \%-125 \mathrm{mg}$ of ropivacaine combined with $75 \mathrm{mcg}$ of clonidine). As adjuvant analgesia, all patients received analgesics and anti-inflammatory drugs in fixed doses and schedules, opioids being made available for occasional use, if necessary. This analgesia protocol (used after the patient leaves the operating room) did not change during the entire study period.

Patients were followed up by the orthopedic clinic throughout the postoperative period. Patients were encouraged to ambulate soon after the recovery of peripheral nerve block. During the four years of evaluation, the following factors were considered as criteria for hospital discharge: hemoglobin greater than $9.0 \mathrm{~g} / \mathrm{dL}$ without hemodynamic repercussions, walking with walker, assisted performance of activities of daily living, and visual analog scale for pain not exceeding three.
This study was approved by the Ethics Committee at Madre Teresa Hospital, Belo Horizonte, MG, Brazil, and written informed consent was obtained from each participant prior to inclusion in the study.

\section{Results}

For data analysis, patients were divided into two groups according to whether or not they were nursed postoperatively in the intensive care unit (ICU).

In 2009 and 2010, the average LS was 74 and 75.2 hours, respectively, in the group that did not stay in the ICU postoperatively. In the same period, for the group that required hospitalization in the ICU, the average LS was 138.7 hours in 2009 and 90.25 hours in 2010. In 2009 and 2010 , the rate of readmission within 30 days was $0 \%$ for both groups.

In 2011 and 2012, after the peripheral nerve block began to be used, the group that did not require ICU care presented average LS of 56.52 hours and 53.72 hours, respectively. In the group treated in the ICU, the average LS in 2011 was 79.8 hours and 52.91 hours in 2012. In 2011, the rate of readmission within 30 days was $3.44 \%$ (deep vein thrombosis, superficial wound infection and joint manipulation), and 1\% in 2012 (superficial surgical site infection and deep vein thrombosis).

\section{Discussion}

Financial assessment has been increasingly emphasized in cost/benefit analyses of surgical procedures. ${ }^{18}$ The total cost of reconstructive procedures has been addressed by many researchers. ${ }^{19,20}$ Barber and Healy ${ }^{21}$ concluded that the total expenditure of arthroplasties can be better regulated when implant and hospital supplies prices are controlled directly; provided that the medical recommendations are good. ${ }^{21}$

LS after TKA is influenced by several factors. Some are related to the patients and their comorbidities, others include cultural, social and economic issues. Some health systems remunerate hospitals according to the number of days in hospital and not the procedure. ${ }^{4,5} \mathrm{~A}$ more familiar and pleasant atmosphere, as well as the quality of social assistance, can also interfere with the LS.

Multimodal pain control is important in peri and postoperative periods and relates directly to the LS. It can be achieved through the use of COX-2 inhibitors, steroids, peripheral nerve block and intra-articular injections. These actions may reduce the use of opioids and their potential side effects. ${ }^{22-31}$ Postoperative analgesia with the use of peripheral nerve blocks is not new. Its benefit has been studied and described for some time, with proven pain 
control postoperatively, low rate of complications and side effects, and shorter LS. ${ }^{28-30}$

A 2009 study analyzing the average length of hospital stay after TKA in Europe has identified Germany as having the highest average LS: 8 days. In the UK, this period varied between 6 and 8 days in 2012. In Spain, in 2009, the average LS was 3 days. ${ }^{32-34}$ Initiatives to reduce this period have been taken in several countries, including the creation of a protocol called "fast track". 8,35 In Canada, this initiative reduced the average LS from 116 to 47 hours in 2011. In Denmark, from 2000 to 2009, there was a reduction in LS from 10-11 days to 4 days, after the introduction of clinical and organizational care protocols. ${ }^{8}$ Our study showed that, in addition to usual care during the peri and postoperative period of patients undergoing TKA, pain control is a key factor in reducing the length of stay, regardless of stay in the ICU.

Studies on readmission after orthopedic procedures are relatively contradictory; however, data related to arthroplasties are often used. ${ }^{35}$ Vorhies et al. ${ }^{36}$ found a $6.8 \%$ readmission rate within 30 days while assessing Medicare data regarding total hip arthroplasty. ${ }^{36}$ Bozic et al. ${ }^{37}$ while examining arthroplasties, found a $4 \%$ readmission rate within thirty days after surgery among 182,146 patients. ${ }^{37}$ In this study, in 2009 and 2010, the readmission rate was $0 \%$ and in 2011 and 2012, 3.44\% and 1\%, respectively. None of the readmissions was motivated by problems related to pain control.

The benefit of shorter LS is notorious. ${ }^{18-20,22}$ The lower risk of contact with bacteria commonly found in hospital environments and the lower chance of prolonged immobilization-related events are examples. Measuring the direct economic impact of this strategy is also an aspect of interest. Despite the many costs involved in TKA, the reduction of approximately $30 \%$ in LS can safely represent significant savings for the patient, the institution and for the health system as a whole.

Retrospective analyzes do not reveal a direct relationship between decreased LS and analgesic control. Other factors may have affected disease progression and decreased LS during this period. The surgeon's improved technique and learning curve, and greater experience of hospital staff can also interfere with the evaluation of the LS. The choice of evaluating cases treated by a single surgeon with over 20 years experience in TKA was an attempt to minimize this factor, as well as the fact that this institution is a place for teaching and research. Clinical follow-up and pre-, peri- and postoperative control are key to proper control of several variables related to LS.

\section{Conclusion}

According to this study, the use of femoral and sciatic nerve blocking after total knee arthroplasty allowed significant reduction in hospital stay.

\section{Resumo}

Redução do tempo de internação após artroplastia total do joelho - Influência do bloqueio do nervo femoral e do nervo ciático.

Objetivo: avaliar a mudança no tempo de permanência hospitalar (PH) no pós-operatório de artroplastia total do joelho (ATJ) após a utilização do bloqueio dos nervos femoral e ciático.

Métodos: os prontuários de 287 pacientes foram avaliados, levando-se em consideração o número de horas de internação, o percentual e o motivo de reinternação em 30 dias, bem como as complicações associadas, sendo divididos em dois grupos de acordo com a permanência ou não no centro de terapia intensiva (CTI). Durante os anos de 2009 e 2010, a anestesia utilizada para a realização dos procedimentos foi a raquianestesia isolada. A partir de 2011, o bloqueio dos nervos femoral e ciático foi introduzido.

Resultados: no período entre 2009 e 2012, o tempo médio de PH variou entre 74 horas, em 2009, e 75,2 horas, em 2010. A PH média em 2011 foi de 56,52 horas e de 53,72 horas em 2012, no grupo de pacientes que não permaneceram no CTI no pós-operatório. No mesmo período, no grupo que precisou de internação no CTI, a PH média foi de 138,7 horas em 2009; 90,25 horas em 2010; 79,8 horas em 2011 e 52,91 horas em 2012. Em 2009 e 2010, a taxa de reinternação foi de $0 \%$, e em 2011 e 2012, $3,44 \%$ e $1 \%$, respectivamente.

Conclusão: de acordo com este estudo, a utilização do bloqueio dos nervos femoral e ciático após a ATJ permitiu a redução significativa da $\mathrm{PH}$.

Palavras-chave: prótese do joelho, tempo de internação, adjuvantes anestésicos.

\section{References}

1. Ranawat CS, Flynn WF Jr., Saddler S, Hansraj KK, Maynard MJ. Long-term results of the total condylar knee arthroplasty. A 15-year survivorship study. Clin Orthop Relat Res. 1993;286:94-102.

2. Ritter MA, Berend ME, Meding JB, Keating EM, Faris PM, Crites BM. Longterm followup of anatomic graduated components posterior cruciateretaining total knee replacement. Clin Orthop Relat Res. 2001;388:51-7.

3. Kurtz SM, Lau E, Schmier J, Ong KL, Zhao K, Parvizi J. Infection burden for hip and knee arthroplasty in the United States. J Arthroplasty. 2008;23:984-91. 
4. Dailey EA, Cizik A, Kasten J, Chapman JR, Lee MJ. Risk factors for readmission of orthopaedic surgical patients.J Bone Joint Surg Am. 2013;95(11):1012-9.

5. Losina E, Walensky RP, Kessler CL, Emrani PS, Reichmann WM, Wright EA, et al. Cost-effectiveness of total knee arthroplasty in the United States: patient risk and hospital volume.Arch Intern Med. 2009;169:1113-21.

6. Mahadevan D, Walter RP, Minto G, Gale TC, McAllen CJ, Oldman M. Combined femoral and Sciatic nerve block $v$ s combined femoral and periarticular infiltration in total knee arthroplasty: a randomized controlled trial. J Arthroplasty. 2012;27(10):1806-11.

7. Lombardi AV, Berend KR, Adams JB. A rapid recovery program: early home and pain free. Orthopedics 2010;33(9):656

8. Husted H, Hansen HC, Holm G, Bach-dal C, Rud K, Andersen KL, Kehlet H. What determines length of stay after total hip and knee arthroplasty? A nationwide study in Denmark. Arch Orthop Trauma Surg. 2010;130(2):263-8.

9. Beaupre LA, Johnston DB, Dieleman S, Tsui B. Impact of a preemptive multimodal analgesia plus femoral nerve blockade protocol on rehabilitation, hospital length of stay and postoperative analgesia after primary total knee arthroplasty: a controlled clinical pilot study. Scientific World Journal. 2012, 2012;273821.

10. Raphael M, Jaeger M, van Vlymen J. Easily adoptable total joint arthroplasty program allows discharge home in two days. Can J Anaesth 2011;58(10): 902-10

11. Kandasami M, Kinninmonth AW, Sarungi M, Baines J, Scott NB. Femoral nerve block for total knee replacement - a word of caution. Knee 2009;16(2): 98-100.

12. Husted H, Lunn TH, Troelsen A, Gaarn-Larsen L, Kristensen BB, Kehlet H. Why still in hospital after fast track hip and knee arthroplasty? ActaOrthop 2011;82(6):679-84.

13. Raphael M, Jaeger M, van Vlymen J. Easily adoptable total joint arthroplasty program allows discharge home in two days. Can J Anaesth 2011;58(10),902-10.

14. Etches RC, Warriner CB, Badner N, et al. Continuous intravenous administration of ketorolac reduces pain and morphine consumption after total hip or knee arthroplasty. Anesth Analg 1995;81:1175-80.

15. Serpell MG, Millar FA, Thomson MF. Comparison of lumbar plexus block versus conventional opioid analgesia after total knee replacement. Anaesthesia 1991;46:275

16. Horlocker TT, Kopp SL, Pagnano MW, Hebl JR. Analgesia for total hip and knee arthroplasty: A multimodal pathway featuring peripheral nerve block. J Am Acad Orthop Surg 2006;14:126-135.

17. De Lima E, Souza R, Correa CH, Henriques MD, de Oliveira CB, Nunes TA, Gomez RS. Single-injection femoral nerve block with $0.25 \%$ ropivacaine or $0.25 \%$ bupivacaine for postoperative analgesia after total knee replacement or anterior cruciate ligament reconstruction. J Clin Anesth. 2008;20(7):521-7.

18. Smith ID, Elton R, Ballantyne JA, Brenkel IJ. Pre-operative predictors of the length of hospital stay in total knee replacement. J Bone Joint Surg Br Nov 2008;90(11):1435-40

19. Smith ID, Elton R, Ballantyne JA, Brenkel IJ. Pre-operative predictors of the length of hospital stay in total knee replacement. J Bone Joint Surg Br. 2008

20. Healy WL, Rana AJ, Iorio R. Hospital economics of primary total knee arthroplasty at a teaching hospital. Clin Orthop Relat Res Jan 2011;469(1):87-94

21. Barber TC, Healy WL. The hospital cost of total hip arthroplasty. A comparison between 1981 and 1990. J Bone Joint Surg Am. 1993;75(3):321-5.

22. Essving P, Axelsson K, Kjellberg J, Wallgren O, Gupta A, Lundin A. Reduced hospital stay, morphine consumption, and pain intensity with local infiltration analgesia after unicompartimental knee arthroplasty. Acta Orthop. 2009;80(2):213-9.

23. Ibrahim MS, Khan MA, Nizam I, Haddad FS. Peri-operative interventions producing better functional outcomes and enhanced recovery following total hip and knee arthroplasty: an evidence-based review. BMC Med. $2013 ; 13 ; 11: 37$

24. Singelyn FJ, Deyaert M, Joris D, Pendeville E, GouverneurJM. Effects of intravenous patient-controlled analgesia with morphine, continuous epidural analgesia, and continuous three-in-one block on postoperative pain and knee rehabilitation after unilateral total knee arthroplasty. Anesth Analg 1998;87:88-92.

25. Hebl JR, Kopp SL, Ali MH, Horlocker TT, Dilger JA, Lennon RL, et al. A comprehensive anesthesia protocol that emphasizes peripheral nerve blockade for total knee and total hip arthroplasty. J Bone Joint Surg Am 2005;87:6370 .

26. Parvizi J, Miller AG, Gandhi K. Multimodal pain management after total joint arthroplasty. The Journal of Bone and Joint Surgery, Volume 93-A d Number $11 \mathrm{~d}$ June 1, 2011.

27. Halazynski TM, Saidi N, Lopez J. Acute pain management for elderly highrisk and cognitively impaired patients: rationale for regional analgesia. In Sinatra RS, de Leon-Casasola OA, Ginsberg B, Viscusi ER, editors. Acute pain management. $1^{\text {st }}$ ed. New York: Cambridge University Press; 2009. p 514-36.

28. Chelly JE, Greger J, Gebhard R, Coupe K, Clyburn TA, Buckle R, Criswell A. Continuous femoral blocks improve recovery and outcome of patients undergoing total knee arthroplasty. J Arthroplasty. 2001;16:436-45.

29. Jin F, Chung F. Multimodal analgesia for postoperative pain control. J Clin Anesth 2001;13:524-539.

30. Buvanendran A, Kroin JS, Tuman KJ, Lubenow TR, Elmofty D, Moric M, Rosenberg AG. Effects of perioperative administration of a selective cyclooxygenase 2 inhibitor on pain management and recovery of function after Knee replacement: A randomized controlled trial. JAMA 2003;290:24112418 .

31. Carvalho Jr. LH, Rezende PM, Castro CA, Soares LM, Gonçalves MBJ. Bupivacaína, epinefrina e morfina na analgesia pós-artroplastia total do joelho. Rev Bras Ortop 2006;41(9):347-51.

32. The Health and Social Care Information Centre. Hospital Episode Statistics: Finalised Patient Reported Outcome Measures (PROMs) in England: April 2010 to March 2011. August 2012 [http://www.hesonline.nhs.uk/Ease/ servlet/ContentServer?siteID=1937\&categoryID=207].

33. BQS Institut für Qualität und Patientensicherheit. Bundesauswertung 2009 http://www.bqs-outcome.de.

34. Jimenez-Garcia R, Villanueva-Martinez M, Fernandez-de-Las- Penas C, Hernandez-Barrera V, Rios-Luna A, et al. Trends in primary total hip arthroplasty in Spain from 2001 to 2008: Evaluating changes in demographics, comorbidity, incidence rates, length of stay, costs and mortality. BMC Musculoskelet Disord 2011;12:43.

35. Bini SA, Fithian DC, Paxton LW, Khatod MX, Inacio MC, Namba RS. Does discharge disposition after primary total joint arthroplasty affect readmission rates?J Arthroplasty 2010;25(1):114-7.

36. Vorhies JS, Wang Y, Herndon J, Maloney WJ, Huddleston JI. Readmission and length of stay after total hip arthroplasty in a national Medicare sample. J Arthroplasty 2011;26(6 Suppl):119-23

37. Bozic KJ, Maselli J, Pekow PS, Lindenauer PK, Vail TP, Auerbach AD. The influence of procedure volumes and standardization of care on quality and efficiency in total joint replacement surgery. J Bone Joint Surg Am. 2010;92(16):2643-52 